\title{
Factors affecting job satisfaction in Turkish forestry
}

\author{
Murat Köse $^{a}$ (iD, İsmet Daşdemir ${ }^{b}$ * (D), Seçil Yurdakul Erol ${ }^{c}$ (D) , Hasan Tezcan Yıldırım ${ }^{c}$ (i)
}

\begin{abstract}
Achieving job satisfaction of employees in today's forestry is an undeniable fact in terms of successful resource management. This study aims at examining the most significant factors affecting job satisfaction in Turkish forestry. Two different questionnaires were applied to 496 interviewees from two different interest groups associated with the forestry section of the Ministry of Forestry and Water Affairs in the nine geographical regions of Turkey. People to be interviewed were determined using the layered-simple random sampling method. The obtained data were evaluated via descriptive statistics, and also, whether the ideas of the interviewees related to the most significant factors affecting the job satisfaction differ according to the regions, the units studied, the task and the experience were inspected by the Kruskal-Wallis $\mathrm{H}$ Test. The different groups were determined via the Duncan Test. Accordingly, the vast majority of interviewees identified "unfair and incompetent personnel policy" and "political pressures" as the most significant factors affecting the work efficiency in the Forestry Organization. On the other hand, the majority of employees are satisfied from their works and they think "the feeling to be useful to the community" as the most important factor affecting job satisfaction. Similarly, the majority of employees have "medium level" satisfaction with the wages they receive and they are open to share their opinions on issues related to forestry. Also, most of the interviewees have the idea that the management and inspection mentality which is far from political, social and administrative pressures will increase the job satisfaction. Likewise, $75 \%$ of employees feel unsafe in any legal inquiry about the task. All these negativities were revealed and interpreted as factors reducing job satisfaction and so success. According to these results, some suggestions were developed towards increasing job satisfaction.
\end{abstract}

Keywords: Job satisfaction in forestry, Working conditions, Workload, Organizational expectations, Communication and cooperation

\section{Türkiye ormancılığında iş doyumunu etkileyen faktörler}

\begin{abstract}
Özet: Günümüz ormancılığında çalışanların iş doyumunu sağlamak başarılı bir kaynak yönetimi açısından yadsınamaz bir gerçektir. Bu çalışmanın amacı, Türkiye ormancılığında iş doyumunu etkileyen en önemli faktörleri incelemektir. Bu amaçla, Orman ve Su İşleri Bakanlığının ormancılık birimlerini kapsayacak şekilde, Türkiye çapında, dokuz coğrafik bölgede iki farklı ilgi grubundan oluşan toplam 496 denek üzerinde iki farklı anket uygulaması yapılmıştır. Görüşülecek ve anket yapılacak kişiler, katmanlı-basit rastgele örnekleme yöntemine göre belirlenmiştir. Elde edilen veriler tanımlayıcı istatistiklerle değerlendirilmiş, deneklerin iş doyumunu etkileyen en önemli faktörlerle ilgili düşüncelerinin bölgelere, çalışılan birimlere, göreve ve deneyime göre farklı olup olmadığı Kruskal-Wallis H Testi ile denetlenmiş ve farklı gruplar Duncan Testi ile belirlenmiştir. Buna göre deneklerin büyük çoğunluğu ormancılık örgütünde iş verimini etkileyen en önemli faktörler olarak, "adil ve liyakate dayalı olmayan personel politikası" ve "politik baskıları" tanımlamıştır. Öte yandan, çalışanların çoğunluğu yaptığı işten memnuniyet duymakta ve "topluma faydalı olma duygusunu" iş memnuniyetini etkileyen en önemli faktör olarak görmektedir. Benzer şekilde, çalışanların çoğunluğu aldıkları ücretlerden "orta düzey" memnuniyete sahiptir ve ormancılıkla ilgili konularda görüşlerini paylaşmaya açıktır. Yine deneklerin çoğunluğu siyasal, sosyal ve idari baskılardan uzak bir yönetim ve denetim anlayışının iş doyumunu artıracağını düşünmektedir. Keza çalışanların \%75'i görevle ilgili herhangi bir hukuksal sorunda kendilerini güvende hissetmedikleri görüşündedir. Bütün bu olumsuzluklar iş doyumunu ve dolayısıyla başarıyı azaltan faktörler olarak ortaya konmuş ve yorumlanmıştır. Elde edilen bu sonuçlara göre iş doyumunun artırılmasına yönelik bazı öneriler geliştirilmiştir. Anahtar kelimler: Ormancılıkta iş doyumu, Çalışma koşulları, İş yükü, Örgütsel beklentiler, İletişim ve dayanışma
\end{abstract}

\section{Introduction}

Job satisfaction is the positive or negative evaluation that employees develop in relation to the work they do and the organization they work with (Sarode and Shirsath, 2014; Agbozo et al., 2017). In another approach, job satisfaction includes the pleasure and happiness that employee receives from the business and factors related to the business, and the sum of the emotional reactions related to the job (Chimanikire et al., 2007; Chen, 2008; Eğinli, 2009). In addition to the varying scientific work on job satisfaction, organizations have tendency to pay more attention to this issue. Yet, the low level of job satisfaction leads to a decline in the productivity of the employees, the decrease of the commitment, the physical and psychological health problems. In addition, it leads to an increase in absenteeism and staff turnover, the increase of conflicts and decrease of efficiency and productivity of organizations (Anderson, 2013; Soysal and Tan, 2013). On the other hand, high job satisfaction affects the motivation, productivity and
凶 a Çanakkale Onsekiz Mart University, Bayramiç Vocational School, Çanakkale, Turkey

b Bartın University, Faculty of Forestry, Bartın, Turkey

İstanbul University Cerrahpaşa, Faculty of Forestry, İstanbul, Turkey

@ * Corresponding author (İletişim yazarı): idasdemir@ bartin.edu.tr

$\checkmark \quad$ Received (Geliş tarihi): 11.08.2020, Accepted (Kabul tarihi): 01.09.2020
Citation (Atıf): Köse, M., Daşdemir, İ., Yurdakul Erol, S., Yildırım, H.T., 2020. Factors affecting job satisfaction in Turkish forestry. Turkish Journal of Forestry, 21(3): 304-317. DOI: $\underline{10.18182 / \text { tjf. } 779371}$ 
organizational commitment of the employees positively and increases the quality of life (Glisson and Durick, 1998; Özcan, 2011; Hoş and Oksay, 2015; Lund et al., 2018). Furthermore, employees with a high level of job satisfaction do not only positively impact the success of the organization, but also ensure job satisfaction for the employees which is considered as a social task for the organizations (Hardy and Koontz, 2010; Akşit Aşık, 2010). In organizations with higher job satisfaction, increasing the performance of the employees leads to the increase of organizational efficiency and the strengthening of employees' commitment to work (Erdil et al., 2004; Keleş, 2007).

In fact, job satisfaction is a complex component pledging state having been constituted by the effect of many factors (Coomber and Barriball, 2007). Factors affecting job satisfaction in general are ranked as organizational factors, group factors, individual factors, cultural factors and environmental factors (Gupta and Koontz, 2019; Örücü et al., 2006; Özkalp et al., 2013). Organizational factors take into account wage, rise opportunities, structure and characteristics of work, management policies and working conditions. Group factors include attitudes of colleagues, attitudes and behaviors of managers, consultants and supervisors (Hitka et al., 2019). Individual factors include individual needs and expectations, business interests, cultural factors; beliefs, values and attitudes, and environmental factors include economic, social and governmental factors. On the other hand, Nguyen et al. (2003) ranked the factors affecting job satisfaction as wages, career opportunities, working environment and occupational safety. Opkara (2002) ranks the factors affecting job satisfaction as career opportunities, relationships among employees, job itself, management and wages. From an organizational and managerial point of view; it can be said that job satisfaction is influenced by working conditions and workload (personnel policy, political and administrative pressures, remuneration, organizational structure, control system, financial problems, opportunity to apply ideas and experiences etc.), organizational expectations, communication, audit and solidarity factors.

The employees' expectations from the organization increases and diversifies due to the increase in the level of education of employees, the increasing competition conditions and the globalization process. Acting in this paradigm, organizations have been making efforts towards meeting employees' expectations in order to improve employee motivation and performance. As the level of meeting employees' expectations and organizational support increase, employees make more efforts in order to realize the goals of the organization, and increase organizational commitment (Rhoades and Eisenberger, 2002; Köse and Gönüllüoğlu, 2010). Employees have a variety of expectations when attending an organization (a good wage, promotion, peaceful and willing work, success, dignity, etc.). Likewise, organizations have the desire to have welltrained individuals of particular quality, traits and competencies, to benefit from their knowledge and skills at the maximum level and to achieve their goals, that is, to be successful (Iversen et al., 2002; Sanchez-Sellero et al., 2018). On one hand, the organization is expected to embrace its employees, expect them some qualified workforce and success, on the other hand, employees are expected to provide some aid by internalizing the goals and values of the organization, and for this purpose, volunteering various duties and thus, integrating them with the organization and this attempt shall provide a satisfaction indicating the realization of the organizational expectations on the working staff side. Individuals who internalized the organizational expectations integrate and identify themselves within the organization (Daşdemir, 1998; Zidane et al., 2016; Meng and Berger, 2019). Therefore, meeting of the expectations is closely related to the employee motivation and job satisfaction.

Factors affecting job satisfaction due to individual differences can vary among employees. However, organizational expectations, social security and work security, training and personal development possibilities, level of organizational position, organizational structure and organizational culture, opportunities for promotion and performance appraisal, expectations on working conditions and personal rights may also affect the job satisfaction (Porter and Lawler, 1968; Küçük and Bayuk, 2007; Arnold and Silva, 2011; Borca and Baesu, 2014). In addition, factors such as the staff, equipment and funds, organizational structure and management mentality also affect success and job satisfaction.

Organizational communication is the element that provides interaction between individuals in the organization for the survival of the organization and the realization of organizational objectives. Organizational structure, which is an open system that affects its environment and is also affected by its environment, includes the flow, direction and means of organizational communication messages (Akınc1, 1998; Hadikusumo et al., 2017). Organizational communication is needed to ensure coordination within the organization, to share information and to achieve consensus. Nevertheless, it is an indispensable necessity for organizations to continue their existence with the support of the environment, to make important and appropriate decisions by exchanging information (Ölçer and Koçer, 2015; Park et al., 2017). Communication and intelligibility make up the process of connection among people (Tosun 1981; Wang, 2018). Our era may be referred as the age of information, technology and communication. The era strongly requires the establishment of, a good communication and intelligibility network within the modern organizations. Communication and intelligibility help to provide information communication in the horizontal and vertical direction within the organization, to process the decision-making and implementation processes effectively, to solve problems, to create a peaceful and productive working environment, to achieve job satisfaction and to reach the business aims (Daşdemir, 1998; Matilla-Santander et al., 2019).

Therefore, based on the factors outlined above, investigation of job satisfaction within the scope of human resources management and taking the necessary precautions accordingly may be expected to increase the success of the Forestry Organization. The problems experienced throughout the country such as the complex structure of the Forestry Organization in Turkey, political pressure on the organization and employees, unequal distribution of human resources to the central and provincial units, various injustices in appointments and promotions (Daşdemir, 1996, 1998; Geray, 1998; Özdönmez et al., 1998; Gümüş, 2014; Yurdakul Erol, 2017) are the main factors affecting human resources management. 
On this topic, Daşdemir (1998) determined the factors affecting managerial and organizational success in forestry as the job satisfaction (organizational expectations), the freedom at work (workplace conditions) and the intelligibility/communication. Y1lmaz et al. (2009) stated that about $60 \%$ of job satisfaction in forestry depends on five basic factors named as: 1) participation in management and promotion opportunities, 2) independence-creativitydignity, 3) conscientious comfort (spiritual peace), 4) technical and managerial competence of managers, 5) wage and working conditions. Yaman (2010) identified "having a beneficial conscience toward the society" as the most significant factor affecting about $40 \%$ of job satisfaction in the forestry. Likewise, Yllmaz and Koçak (2008) revealed that the levels of job satisfaction of the employees of the Eastern Mediterranean Forestry Research Institute is differs depending on age, position, total service period, gender, education level and marital status. Akyüz et al. (2011) investigated the job satisfaction in the Muğla Regional Directorate of Forestry in terms of the quality of job, working conditions, colleagues, communication, corporate image and wage factors. And, Çok et al. (2017) studied the effects of the factors of the communication among colleagues, the desire to come office, the feeling of accomplishment in the work, the duration of the work, establishing the cooperation in the working environment, appreciation and rewarding, career opportunities, professional development possibilities, financial gain and physical environment at work in order to materialize the feeling of satisfaction of employees of the Elazı̆̆ Regional Directorate of Forestry. All these studies indicate that factors such as the working conditions, workload and organizational expectations, communication/intelligibility, inspection and solidarity are effective on those working as managers and technical staff in the Forestry Organization in Turkey related to the job satisfaction.

Turkish forestry is mainly based on public management and private ownership. The organizations affiliated to the Ministry of Forestry and Water Affairs that are responsible for the management of forest resources in the country are the General Directorate of Forestry (GDF), the General Directorate of Nature Conservation and National Parks (GDNCNP) and the General Directorate of Combating Desertification and Erosion (GDCDE). In order to reach the goals and success in the organization, which is responsible for forest resource management; job satisfaction for the employees of the organization should be established beforehand. In this sense, determining the factors affecting the job satisfaction of the employees of the organization is significant. Previous works on the subject were usually conducted in a specific region or unit. A study of job satisfaction based on the opinions of both employees and experts was conducted in the scale of Turkey before.

Therefore, the study was carried out in order to examine and evaluate factors such as the working conditions and workload (personnel policy, political and administrative pressures, pricing, organizational structure, control system, financial problems, possibility of applying ideas and experiences etc.), the organizational expectations, communication, audit and solidarity which they are considered to be effective in job satisfaction of employees working as manager and technical personnel in the Forestry Organization of Turkey from point of view of employees and related experts. The study was carried out over face-to- face interviews and questionnaire study methods with a total of 496 persons, including 463 persons working as managers and technical personnel and 33 persons case experts in the forestry units (GDF, GDNCNP and GDCDE) of the Ministry of Forestry and Water Affairs. The results obtained are expected to draw attention to the importance of human resources and management in terms of sustainable forest resource management, improve the job satisfaction of the employees and contribute to the literature.

\section{Material and method}

\subsection{Material}

This study was carried out within the scope of the units (GDF, GDNCNP and GDCDE) attached to the Ministry of Forestry and Water Affairs in Turkey. In the scale of Turkey, the nine provinces (İstanbul, İzmir, Antalya, Adana, Bolu, Trabzon, Erzurum, Şanlıurfa, Ankara) representing the nine geographical regions in terms of forestry activities (forest planning and management, wood production and marketing, non-wood services of forests, forest protection, afforestation, forest-society relations, etc.) were included in the study.

In the mentioned provinces, face-to-face interviews were conducted, and a questionnaire was applied on two different interest groups (employees of the Forestry Organization and subject experts). Two different questionnaire forms were developed for this purpose. In the questionnaire forms, open and closed-ended questions were mainly included in issues related to the factors affecting work efficiency in the Forestry Organization, the possibility of applying scientific knowledge, the ideas and experiences, the possibility to make and apply decisions in accordance with local conditions, the realization of organizational expectations, the level of satisfaction with work done and received wage, the basic factors affecting job satisfaction, the communication/intelligibility between subordinates and superiors, the supervision of employees and solidarity among employees. In the interviews, the questions which can be determined more clearly about the results obtained by the semi-structured interview technique and the participants' point of view were included. The questionnaires were handed over all of the participants and applied by face-to-face interview technique. In the interviews, the opinions of the participants were recorded and then evaluated and interpreted. The data obtained from the survey, interview study and literature reviews were used as the material in the research.

\subsection{Data collection method}

The number of employees $(\mathrm{N}=4704)$ working as managers an technical staff in the central and provincial organizations of the forestry section of the Ministry of Forestry and Water Affairs constitute the research universe. Within the scope of the research, the number of the organization employees to be surveyed was calculated by following formula (Eq. 1) related to sample size in limited societies (Orhunbilge, 2000; Daşdemir, 2016);

$$
\mathrm{n} \geq \frac{\mathrm{Z}^{2} \mathrm{xNxpxq}}{\mathrm{NxD}^{2}+\mathrm{Z}^{2} \mathrm{xpxq}}
$$


Where $n$ is the size of the sample, $Z$ is reliability coefficient ( $\mathrm{Z}=1.96$ for $95 \%$ of confidence level), $N$ is the size of the population $(\mathrm{N}=4704), p$ is the existence possibility of the measured feature in the population, $q$ is absence possibility of the measured feature in the population $(\mathrm{p}=0.5 ; \mathrm{q}=0.5)$ and $\mathrm{D}$ is acceptable sampling error (0.05).

According to these data, $n$ value was calculated as 355 and it was determined that there should be interviewed at least these employees. Multiplying the calculated $\mathrm{n} / \mathrm{N}$ coefficient with the number of employees in each region, the minimum number of participants to be interviewed in each region was determined. That is, the sampling in the share rate was applied in each layer. However, in this study; the 355 number was exceeded 463 participants were interviewed. Accordingly, interviews and survey studies were conducted with 71 employees in İstanbul, 64 in İzmir, 30 in Antalya, 64 in Adana, 72 in Bolu, 43 in Trabzon, 80 in Ankara, 23 in Erzurum and 25 in Sanliurfa in the Forestry Organization (GDF, GDNCNP and GDCDE). The persons interviewed and surveyed in each region were determined according to the random sampling method. Thus, layeredsimple random sampling method was applied in the research.

Additionally, a questionnaire study was conducted with 33 specialists (those who have scientific studies on forest resources management or who have worked as a manager in the Forestry Organization for many years and who have knowledge on organization management and restructuring) according to the method of full area measurement in the provinces within the scope of the research. Thus, the survey study was carried out with 496 participants in all of the two interest groups.

The survey and interview studies were conducted in 2016. Questionnaire application was firstly started with preliminary experiment. In the preliminary experiment, the assessments of the participants about the questionnaire application, the suitability of the designed questionnaires, the clarity of the questions and the missing parts were determined, and necessary corrections were made. Then, face-to-face interviews were conducted with the participants, the importance of the subject was explained, and the application of the questionnaire was carried out.

\subsection{Data assessing method}

The questions / data obtained from the questionnaires prepared and applied for the two different interest groups most of which are qualitative, are defined and digitized as variables in Table 1 to serve the purpose of the study.

The data obtained in the research were evaluated with descriptive statistics, the Kruskal-Wallis (K-W) H Test and Duncan Test; the results were shown in tables. Excel-2010 and SPSS (22.0 version) programs were used to evaluate the data.

\section{Results}

\subsection{General results and evaluations related to interest groups}

The four hundred and sixty-three of the 496 people interviewed and surveyed have worked in the Forestry Organization as manager and technical staff. Fifty-nine percent of the surveyed organization employees are engineers, $11 \%$ are forest enterprise chiefs, $2 \%$ are forest operation manager assistants, $2 \%$ are forest operation managers, $24 \%$ were branch managers, $2 \%$ forest regional directors, forest regional director assistants or head of departments. In the same way, $52 \%$ of the 33 subject matter experts interviewed are the employees of the Ministry of Forest and Water Affairs, $42 \%$ are academicians in forest faculties and $6 \%$ are retired forestry engineers.

Throughout the country, of the 463 participants working as managers and technical staff in the forestry sector $65 \%$ have $0-5$ years working experience, $22 \%$ of them worked 610 years and $13 \%$ worked 11 years or more. That is, $87 \%$ of the personnel working in the administrative duties carried on their duties for a maximum of 10 years. $51 \%$ of participants have 20 years of experience (low and medium) and, $49 \%$ of them have very significant experience $(\geq 21$ years). $73 \%$ of the participants graduated from forest engineering departments of forestry faculties. Only $24 \%$ took master's level or a Ph.D. and 3\% additionally completed another faculty. The raised data is a significant development on behalf of qualified managers and technical staff. Approximately $70 \%$ of the participants, who were consulted as expert, completed either post-graduate education or a second faculty.

\subsection{Working conditions and workload}

In this subdivision, the ideas of employees and subject matter experts in the Forestry Organization have been questioned about the most significant factors affecting the work efficiency in the Forestry Organization, the possibility of applying scientific knowledge, ideas and experiences in administrative and technical matters, and the possibility of taking and applying decisions in accordance with local conditions. The ideas of the participants on these topics were compiled, and the results were given in Table 2 as percentages. In addition, the following comments and evaluations were made by testing statistical analyzes (Table 3) whether the participants' ideas on these participants differ according to regions, working units, duty and experience.

About $20 \%$ of the employees of the organization and $17 \%$ of the experts considers "the personnel policy not based on fair and incompetent" and regards it as the most significant factor affecting the work efficiency in the Forestry Organization. 19\% of the experts and 12\% of the employees identified "political pressures" as the prime importance factors (Table 2). About this matter, the opinions of the employees of the organization don't significantly differ according to the working units. However, there is a difference in the $99 \%$ confidence level according to the working regions, the position and experience (Table 3). Accordingly, while the participants working in the regions of Ankara, Antalya and İzmir regard the most significant factor affecting work efficiency as "unfair and incompetent personnel policy"; the participants working in the regions of İstanbul, Bolu, Trabzon, Erzurum, Şanliurfa and Adana generally evaluate "the administrative and bureaucratic obstacles", "political pressures", "inadequacy of remuneration, and not being of rewarding system based on performance" as the most significant factors affecting the work efficiency. While those on duty as engineer, forest operation manager, branch manager, regional director and their assistant make out that the most significant factor affecting the work efficiency is mostly 
"the personnel policy not based on fair and competence"; those on duty as forest operation chief and forest operation manager assistant mostly consider "the administrative and bureaucratic obstacles", "political pressures", "inadequacy of remuneration, and not having rewarding system based on performance" as the most significant factors affecting the work efficiency. Moreover, those who are high and very high experienced ( $\geq 21$ years) consider "the unfair and incompetent personnel policy" as the most significant factor affecting work efficiency; those with less and medium experienced ( $\leq 20$ years) consider "the administrative and bureaucratic obstacles", "political pressures", "inadequacy of remuneration, and not being of rewarding system based on performance" as the most significant factors.

Table 1. The identification of research variables

\begin{tabular}{|c|c|c|c|c|c|}
\hline Class & No & Name & Definition and Digitization & Unit & Scale \\
\hline \multirow[t]{3}{*}{ 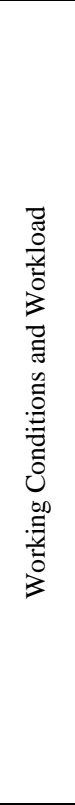 } & 1 & $\begin{array}{l}\text { The most significant factors affecting } \\
\text { work efficiency }\end{array}$ & $\begin{array}{l}\text { 1) The unfair and incompetent personnel policy } \\
\text { 2) Administrative and bureaucratic obstacles } \\
\text { 3) Attaching insufficient significance to training, research } \\
\text { and specialization } \\
\text { 4) Political pressures } \\
\text { 5) The inadequacy of remuneration, and the rewarding } \\
\text { system which is not based on performance } \\
\text { 6) The problems arising from the Forestry Organization } \\
\text { structure } \\
\text { 7) Lack of harmony in working environment and team } \\
\text { working } \\
\text { 8) The value judgments of society, and social pressures } \\
\text { 9) The fear of exposure to judicial and administrative } \\
\text { audit } \\
\text { 10) Financial problems, inadequacy of technology, } \\
\text { equipment and physical conditions } \\
\text { 11) Pressures of local governments and other public } \\
\text { institutions } \\
\text { 12) The multidisciplinary structure of forestry activities } \\
\text { 13) Other factors }\end{array}$ & \multicolumn{2}{|c|}{$\begin{array}{l}\text { The preference } \\
\text { percentages of } \\
\text { employees and expert } \\
\text { groups } \\
(\%) \\
(0-20)\end{array}$} \\
\hline & 2 & $\begin{array}{l}\text { The possibility to apply scientific } \\
\text { ideas and experiences }\end{array}$ & $\begin{array}{l}\text { None }=1, \text { Very Low }=2, \text { Medium }=3, \text { High }=4, \text { Very } \\
\text { High }=5\end{array}$ & -- & $1-5$ \\
\hline & 3 & $\begin{array}{l}\text { The possibility to make and apply } \\
\text { decisions in accordance with the local } \\
\text { conditions }\end{array}$ & $\begin{array}{l}\text { None }=1 \text {, Very Low }=2, \text { Medium }=3 \text {, High }=4 \text {, Very } \\
\text { High }=5\end{array}$ & -- & $1-5$ \\
\hline \multirow{5}{*}{ 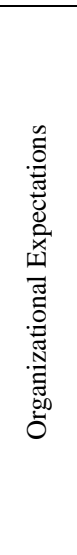 } & 4 & $\begin{array}{l}\text { The realization of the expectations } \\
\text { while participating in the organization }\end{array}$ & $\begin{array}{l}\text { None }=1, \text { Very Low }=2, \text { Medium }=3, \text { High }=4 \text {, Very } \\
\text { High }=5\end{array}$ & -- & $1-5$ \\
\hline & 5 & $\begin{array}{l}\text { The belief on the materialization of } \\
\text { the expectations for the future }\end{array}$ & $\begin{array}{l}\text { None }=1, \text { Very Low }=2, \text { Medium }=3, \text { High }=4, \text { Very } \\
\text { High }=5\end{array}$ & -- & $1-5$ \\
\hline & 6 & $\begin{array}{l}\text { Being pleased with the professional } \\
\text { position }\end{array}$ & $\begin{array}{l}\text { None }=1, \text { Very Low }=2, \text { Medium }=3, \text { High }=4, \text { Very } \\
\text { High }=5\end{array}$ & -- & $1-5$ \\
\hline & 7 & $\begin{array}{l}\text { The main factors affecting job } \\
\text { satisfaction }\end{array}$ & $\begin{array}{l}\text { 1) The feeling to be beneficial to the society } \\
\text { conscientiously } \\
\text { 2) Working independently and applying creativity } \\
\text { 3) The appropriate working conditions } \\
\text { 4) The participation in administration and decisions } \\
\text { 5) Having a working reward system } \\
\text { 6) Having adequate wages and social security } \\
\text { 7) Other factors } \\
\text { 8) Receiving social respect }\end{array}$ & $\begin{array}{r}\text { Th } \\
\text { pe } \\
\text { emplc }\end{array}$ & $\begin{array}{l}\text { ence } \\
\text { es of } \\
\text { d expert }\end{array}$ \\
\hline & 8 & Wage satisfaction & $\begin{array}{l}\text { None }=1, \text { Very Low }=2, \text { Medium }=3, \text { High }=4, \text { Very } \\
\text { High }=5\end{array}$ & -- & $1-5$ \\
\hline \multirow{5}{*}{ 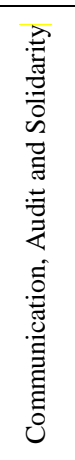 } & 9 & $\begin{array}{l}\text { Having the opportunity to discuss } \\
\text { ideas and views with subordinates }\end{array}$ & $\begin{array}{l}\text { None }=1, \text { Very Low }=2, \text { Medium }=3, \text { High }=4, \text { Very } \\
\text { High }=5\end{array}$ & -- & $1-5$ \\
\hline & 10 & $\begin{array}{l}\text { Having the opportunity to discuss } \\
\text { ideas and views with superiors }\end{array}$ & $\begin{array}{l}\text { None }=1, \text { Very Low }=2, \text { Medium }=3, \text { High }=4, \text { Very } \\
\text { High }=5\end{array}$ & -- & $1-5$ \\
\hline & 11 & $\begin{array}{l}\text { Ideas concerning the audit system } \\
\text { (monitoring and evaluation) }\end{array}$ & $\begin{array}{l}\text { 1) Objective and unbiased audit should be applied } \\
\text { 2) The supervision should be realized by experts } \\
\text { 3) Audit results should be communicated to relevant units } \\
\text { and their implementations should be monitored } \\
\text { 4) Audit frequency should be adjusted well } \\
\text { 5) Other factors }\end{array}$ & \multicolumn{2}{|c|}{$\begin{array}{c}\text { The preference } \\
\text { percentages of } \\
\text { employees group } \\
(\%) \\
(2-32)\end{array}$} \\
\hline & 12 & $\begin{array}{l}\text { Institutional support of the higher } \\
\text { authorities }\end{array}$ & $\begin{array}{l}\text { None }=1, \text { Very Low }=2, \text { Medium }=3, \text { High }=4, \text { Very } \\
\text { High }=5\end{array}$ & -- & $1-5$ \\
\hline & 13 & $\begin{array}{l}\text { The individual support and solidarity } \\
\text { of colleagues }\end{array}$ & $\begin{array}{l}\text { None }=1, \text { Very Low }=2, \text { Medium }=3, \text { High }=4, \text { Very } \\
\text { High }=5\end{array}$ & -- & $1-5$ \\
\hline
\end{tabular}


Table 2. Ideas of participants related to working conditions and workload

\begin{tabular}{|c|c|c|c|}
\hline \multirow{2}{*}{ Question (Feature) } & \multirow{2}{*}{ Option } & \multicolumn{2}{|c|}{ Percentage of Preference $(\%)$} \\
\hline & & Employees & Experts \\
\hline \multirow{13}{*}{$\begin{array}{l}\text { 1. The most significant factors } \\
\text { affecting the work efficiency in } \\
\text { the Forestry Organization }\end{array}$} & a) The administrative and bureaucratic obstacles, & 13 & 13 \\
\hline & b) The political pressures, & 12 & 19 \\
\hline & c) The value judgments of society, and social pressures, & 5 & 2 \\
\hline & d) The pressures of local governments and other public institutions, & 3 & 3 \\
\hline & e) The fear of exposure to judicial and administrative audits, & 4 & 7 \\
\hline & f) Being of multidisciplinary structure of forestry activities, & 3 & 4 \\
\hline & g) Not paying sufficient attention to education, research and specialization, & 13 & 11 \\
\hline & $\begin{array}{l}\text { h) Inadequacy of remuneration, and not being of rewarding system based on } \\
\text { performance }\end{array}$ & 8 & 5 \\
\hline & i) Unfair and incompetent personnel policy, & 20 & 17 \\
\hline & j) Problems arising from forestry organization structure, & 8 & 13 \\
\hline & $\begin{array}{l}\text { k) Financial problems, inadequacy of technology, equipment and physical } \\
\text { conditions, }\end{array}$ & 4 & 0 \\
\hline & $\begin{array}{l}\text { 1) Unharmonious work environment and team work (the conflict with } \\
\text { subordinate-higher and co-workers, the lack of communication etc.), }\end{array}$ & 7 & 6 \\
\hline & m) Other & 0 & 0 \\
\hline \multirow{5}{*}{$\begin{array}{l}\text { 2. The possibility to apply } \\
\text { scientific knowledge, ideas and } \\
\text { experiences }\end{array}$} & a) None & 8 & -- \\
\hline & b) Very low & 31 & -- \\
\hline & c) Medium level & 47 & -- \\
\hline & d) High & 12 & -- \\
\hline & e) Very high & 2 & -- \\
\hline \multirow{5}{*}{$\begin{array}{l}\text { 3. The possibility to take } \\
\text { decisions in accordance with } \\
\text { local conditions and to apply } \\
\text { them }\end{array}$} & a) None & 15 & 0 \\
\hline & b) Very low & 33 & 46 \\
\hline & c) Medium level & 41 & 33 \\
\hline & d) High & 10 & 18 \\
\hline & e) Very high & 1 & 3 \\
\hline
\end{tabular}

In relation to "the possibility of applying scientific knowledge, thought and experiences in administrative and technical matters related to the duty"; while $39 \%$ of the employees of the organization stated that there is "no" or "very low" possibility, $47 \%$ of them think that there is "medium level" and 14\% "considerable" possibility (Table 2). The opinions of the organization employees on this matter don't differ at a significant level according to regions, units, duty and experience (Table 3).

"The possibility of making and applying decisions in accordance with the local conditions apart from central decisions"; $41 \%$ of the organization employees have the opinion that there is "medium level", and $46 \%$ of the experts have the opinion that there is "very low" possibility (Table 2). These ideas of the employees of the organization do not show significant differences depending on the units worked and experience. However, 99\% confidence level differs depending on the working regions and the position. Accordingly, while the participants in Istanbul, Ankara, Şanlıurfa, Adana and Antalya regions mostly have "very low" possibility of taking and applying decisions in accordance with the local conditions; the participants in Bolu, Trabzon, Erzurum and İzmir regions have mostly the "medium level" possibility. Likewise, while those working as forest operation chief, forest operation manager assistant, forest operation manager, branch manager, regional director and assistant have usually "medium level" possibility of making and applying the decisions in accordance with local conditions; the participants working as engineer find usually the possibility of "very low" (Table 3).

\subsection{Organizational expectations}

In this part, the level of realization of the expectations that the participants have when they initially participated in the Forestry Organization, the level of belief on the expectations to be realized in the future will realized, the level of satisfaction from the position, the main factors affecting job satisfaction, and the level of wage satisfaction are questioned. The responses of the participants to the related questions were given in Table 4. In addition, the following comments and evaluations were made by testing with statistical analyzes whether or not participants' ideas on this subject differ according to the regions, the units worked, the duty and the experience (Table 5).

Regarding the question of "to what extent of your expectations were realized when you initially participated in the Forestry Organization", 8\% of the participants answered as a lot, 49\% answered as "medium level", 35\% answered as "very low" and $8 \%$ answered as "none" or "high" (Table 4). That is, the expectations were largely realized as "very low and medium level". There is no significant difference in this respect in the ideas of the employees of the organization according to the units worked and experience. However, it may be determined that there is a significant difference at the $99 \%$ confidence level according to the regions and the duty (Table 5). 
Table 3. Diversity of ideas of participants regarding working conditions and workload according to region, unit, position and experience

\begin{tabular}{|c|c|c|c|c|c|c|c|}
\hline \multirow{3}{*}{ Features } & \multicolumn{3}{|c|}{ The Results of Kruskal-Wallis H Test } & \multicolumn{4}{|c|}{ The Audit of Diversity with Duncan Test } \\
\hline & \multirow{2}{*}{ Criterion } & \multirow{2}{*}{$\begin{array}{l}\text { The value of chi- } \\
\text { square }\end{array}$} & \multirow{2}{*}{ DF } & \multicolumn{4}{|c|}{ Different Groups } \\
\hline & & & & No & Group Elements & $\overline{\mathrm{X}}$ & $\mathrm{N}$ \\
\hline \multirow{6}{*}{$\begin{array}{l}\text { 1. The most significant factors } \\
\text { affecting the work efficiency } \\
\text { in the Forestry Organization }\end{array}$} & \multicolumn{5}{|c|}{ There is no significant difference in terms of the unit worked } & -- & -- \\
\hline & \multirow{2}{*}{\multicolumn{2}{|c|}{ Region }} & \multirow[t]{2}{*}{8} & 1 & $\begin{array}{l}\text { İstanbul, Bolu, Trabzon, Erzurum, Şanlıurfa, } \\
\text { Adana }\end{array}$ & 31.31 & 289 \\
\hline & & & & 2 & Ankara, Antalya, İzmir & 34.27 & 174 \\
\hline & \multirow[b]{2}{*}{ Duty } & \multirow[b]{2}{*}{$25.22^{* *}$} & \multirow[b]{2}{*}{5} & 1 & Operation Chief, Operation Manager Assistant & 26.71 & 61 \\
\hline & & & & 2 & $\begin{array}{l}\text { Engineer, Forest Operation Manager, Branch } \\
\text { Manager, Regional Director and Assistant }\end{array}$ & 34.70 & 402 \\
\hline & Experience & $46.61^{* *}$ & 3 & & $\begin{array}{l}\text { Low and medium experienced }(\leq 20 \text { years }) \\
\text { High and very high experienced }(\geq 21 \text { years })\end{array}$ & $\begin{array}{l}30.40 \\
35.94\end{array}$ & $\begin{array}{l}238 \\
225\end{array}$ \\
\hline $\begin{array}{l}\text { 2. The possibility of applying } \\
\text { scientific knowledge, ideas } \\
\text { and experiences }\end{array}$ & \multicolumn{5}{|c|}{ There is no significant difference in terms of region, unit, duty and experience. } & -- & -- \\
\hline \multirow{4}{*}{$\begin{array}{l}\text { 3. The possibility of taking } \\
\text { decisions in accordance with } \\
\text { local conditions and to apply } \\
\text { them }\end{array}$} & \multicolumn{5}{|c|}{ There is no significant difference in terms of the unit worked and experience } & -- & -- \\
\hline & Region & $22.20^{* *}$ & 8 & $\begin{array}{l}1 \\
2\end{array}$ & $\begin{array}{l}\text { İstanbul, Ankara, Şanlıurfa, Adana, Antalya } \\
\text { Bolu, Trabzon, Erzurum, İzmir }\end{array}$ & $\begin{array}{l}2.33 \\
2.71\end{array}$ & $\begin{array}{l}270 \\
193\end{array}$ \\
\hline & & & & 1 & Engineer & 2.32 & 273 \\
\hline & Duty & $23.32^{* *}$ & 5 & 2 & $\begin{array}{l}\text { Forest Operation Chief, Assistant of Forest } \\
\text { Operation Manager, Forest Operation Manager, } \\
\text { Branch Manager, Regional Director and } \\
\text { Assistant }\end{array}$ & 2.80 & 190 \\
\hline
\end{tabular}

Table 4. Ideas of participants about organizational expectations and job satisfaction

\begin{tabular}{|c|c|c|c|}
\hline \multirow{2}{*}{ Question (Feature) } & \multirow{2}{*}{ Option } & \multicolumn{2}{|c|}{ Percentage of preference $(\%)$} \\
\hline & & Employees & Experts \\
\hline \multirow{5}{*}{$\begin{array}{l}\text { 1. To what level expectations } \\
\text { are met in the Forestry } \\
\text { Organization }\end{array}$} & a) None & 8 & \\
\hline & b) Very low & 35 & \\
\hline & c) Medium level & 49 & \\
\hline & d) High & 8 & \\
\hline & e) Very high & 0 & \\
\hline \multirow{5}{*}{$\begin{array}{l}\text { 2. Level of the belief that the } \\
\text { expectations shall be for the } \\
\text { future will realize }\end{array}$} & a) None & 19 & \\
\hline & b) Very low & 47 & \\
\hline & c) Medium level & 26 & \\
\hline & d) High & 7 & \\
\hline & e) Very high & 1 & \\
\hline \multirow{5}{*}{ 3. Level of work satisfaction } & a) None & 6 & \\
\hline & b) Very low & 25 & \\
\hline & c) Medium level & 44 & \\
\hline & d) High & 21 & \\
\hline & e) Very high & 4 & \\
\hline \multirow{8}{*}{$\begin{array}{l}\text { 4. The main factors affecting } \\
\text { the job satisfaction }\end{array}$} & a) Participation in the administration and decisions & 9 & 12 \\
\hline & b) The working independently and using creativity & 18 & 12 \\
\hline & c) To gain respect in society & 2 & 3 \\
\hline & d) The feeling to be beneficial to the society conscientiously & 41 & 36 \\
\hline & e) Having adequate wages and social security & 7 & 21 \\
\hline & f) The appropriate working conditions (in the field and in the office) & 10 & 12 \\
\hline & $\begin{array}{l}\text { g) The working of the rewarding system (appreciation, promotion, premium, } \\
\text { etc.) }\end{array}$ & 8 & 3 \\
\hline & h) Other & 5 & 0 \\
\hline \multirow{5}{*}{ 5. Level of wage satisfaction. } & a) None & 14 & \\
\hline & b) Very low & 26 & \\
\hline & c) Medium level & 49 & \\
\hline & d) High & 10 & \\
\hline & e) Very high & 1 & \\
\hline
\end{tabular}

While the participants working in the regions of İstanbul, İzmir, Şanlıurfa and Adana feel that the expectations they had when first participating in the Forestry Organization are mostly met at the level of "very low"; the participants working in the regions of Ankara, Bolu, Trabzon, Erzurum and Antalya mostly think that their expectations are met in the "medium level". In this regard according to the duty, while the participants working as engineer, forest operation chief, branch manager think that their expectations generally realized at the level of "very low" and "medium level"; those who on duty as forest operation manager assistant, forest operation manager, region manager and assistant consider that their expectations generally realized at the level of "medium level" and "high" (Table 5).

Regarding the question about "do you believe that your expectations about the future of your profession will be met"; $47 \%$ of the participants working in the Forestry 
Organization answered "very low" and 26\% replied as "medium level" (Table 4). In this respect, there is a significant difference in the opinions of the participants according to the regions, the units and the duty at the level of $99 \%$ confidence, and at the level of $95 \%$ confidence level according to the experience (Table 5). Moreover, employees in the regions of İstanbul, Bolu, Erzurum, Şanlıurfa, Adana, Antalya and İzmir generally believe that their expectations for the future shall be met "very low"; employees in the regions of Ankara and Trabzon generally believe that they will be met "medium level". Depending on the units worked, employees working in the GDF generally think that their expectations will be met "very low"; employees working in the GDNCNP and GDCDE think that their expectations will be met "medium level". On the other hand, those on duty as forest operation chief, forest operation manager assistant, forest operation manager and branch manager mostly believe that their expectation will be met "very low"; those who on duty as regional director and assistant mostly believe that their expectations related to their profession will be met "medium level". Likewise, while those with medium, high and very high experienced
( $\geq 11$ years) generally believe that their expectations will be met "very low"; those with low experienced ( $\leq 10$ years) generally believe that their expectations will be met "very low" and "medium level" (Table 5).

Regarding "wage satisfaction", 69\% of the participants working in the Forestry Organization responded "medium level", "high" and "very high" (Table 4). In this respect, there is no significant difference with respect to the regions worked and the experiences, in the minds of the employees of the organization. However, the study indicated that there is a significant difference at the $95 \%$ confidence level with respect to the units worked and the duty. Likewise, while the GDNCNP and GDCDE employees generally have "medium level" and "high" level, satisfaction with the work they have been doing; the GDF employees are generally satisfied at "very low" and "medium level". On the other hand, while those working as manager, manager assistant, branch manager, regional director and assistant have "medium level" and "high" job satisfaction; those who are on duty as the engineer and forestry chief are pleased in their works at "very low" and "medium level" (Table 5).

Table 5. Diversity of ideas of participants about organizational expectations and job satisfaction according to region, unit, duty and experience

\begin{tabular}{|c|c|c|c|c|c|c|c|}
\hline \multirow{3}{*}{ Features } & \multicolumn{3}{|c|}{ The Results of Kruskal-Wallis H Test } & \multicolumn{4}{|c|}{ The Audit of Diversity with Duncan Test } \\
\hline & \multirow{2}{*}{ Criterion } & \multirow{2}{*}{$\begin{array}{l}\text { The value of } \\
\text { chi-square }\end{array}$} & \multirow{2}{*}{ DF } & \multicolumn{4}{|c|}{ Different groups } \\
\hline & & & & No & Group elements & $\overline{\mathrm{X}}$ & $\mathrm{N}$ \\
\hline \multirow{5}{*}{$\begin{array}{l}\text { 1. Meeting level of } \\
\text { expectations in the } \\
\text { Forestry Organization }\end{array}$} & \multicolumn{5}{|c|}{ There is no significant difference in terms of unit worked and experience } & -- & -- \\
\hline & \multirow{2}{*}{ Region } & \multirow{2}{*}{$25.98^{* *}$} & \multirow{2}{*}{8} & 1 & İstanbul, İzmir, Şanlıurfa, Adana & 2.42 & 224 \\
\hline & & & & 2 & Ankara, Bolu, Trabzon, Erzurum, Antalya & 2.78 & 239 \\
\hline & \multirow[b]{2}{*}{ Duty } & \multirow[b]{2}{*}{$19.99^{* *}$} & \multirow[b]{2}{*}{5} & & Engineer, Operation Chief, Branch Manager & 2.60 & 436 \\
\hline & & & & 2 & $\begin{array}{l}\text { Assistant of Forest Operation Manager, Forest } \\
\text { Operation Manager, Regional Director and Assistant }\end{array}$ & 3.10 & 27 \\
\hline \multirow{8}{*}{$\begin{array}{l}\text { 2. Meeting level of the } \\
\text { future expectations }\end{array}$} & \multirow[t]{2}{*}{ Region } & \multirow[t]{2}{*}{$28.92^{* *}$} & \multirow[t]{2}{*}{8} & & $\begin{array}{l}\text { İstanbul, Bolu, Erzurum, Şanlıurfa, Adana, Antalya, } \\
\text { İzmir }\end{array}$ & 2.20 & 349 \\
\hline & & & & & Ankara, Trabzon & 2.55 & 114 \\
\hline & \multirow[t]{2}{*}{ Unit } & \multirow[t]{2}{*}{$17.74^{* *}$} & \multirow[t]{2}{*}{2} & 1 & GDF & 2.11 & 405 \\
\hline & & & & & GDNCNP, GDCDE & 2.70 & 58 \\
\hline & \multirow[t]{2}{*}{ Duty } & \multirow[t]{2}{*}{$17.18^{* *}$} & \multirow[t]{2}{*}{5} & & $\begin{array}{l}\text { Engineer, Operation Chief, Assistant of Forest } \\
\text { Operation Manager, Forest Operation Manager, } \\
\text { Branch Manager }\end{array}$ & 2.26 & 452 \\
\hline & & & & & Regional Director and Assistant & 3.27 & 11 \\
\hline & \multirow[t]{2}{*}{ Experience } & \multirow[t]{2}{*}{$11.24 *$} & \multirow[t]{2}{*}{3} & & $\begin{array}{l}\text { Those who experienced medium, high and very high } \\
\text { (11 - } 30 \text { years and } \geq 31 \text { years ) }\end{array}$ & 2.15 & 342 \\
\hline & & & & & Those who experienced low ( $\leq 10$ years) & 2.50 & 121 \\
\hline \multirow{5}{*}{$\begin{array}{l}\text { 3. Level of the work } \\
\text { satisfaction }\end{array}$} & \multicolumn{5}{|c|}{ There is no significant difference in terms of region and experience } & -- & -- \\
\hline & Unit & $735^{*}$ & 2 & & GDF & 2.88 & 405 \\
\hline & Unit & 7.35 & 2 & 2 & GDNCNP, GDCDE & 3.20 & 58 \\
\hline & & & & 1 & Engineer, Forest Operation Chief & 2.90 & 325 \\
\hline & Duty & $13.37^{*}$ & 5 & & $\begin{array}{l}\text { Assistant of Forest Operation Manager, Forest } \\
\text { Operation Manager, Branch Manager, Regional } \\
\text { Director and Assistant }\end{array}$ & 3.23 & 138 \\
\hline $\begin{array}{l}\text { 4. The main factors } \\
\text { affecting the job } \\
\text { satisfaction }\end{array}$ & There is no & ficant differen & $\mathrm{n}$ tern & of $\mathrm{re}$ & ion, unit, duty and experience & -- & -- \\
\hline & There is no & ficant differen & $\mathrm{n}$ tern & of $d$ & & -- & -- \\
\hline & & & & & İstanbul, Adana, Antalya, İzmir & 2.32 & 229 \\
\hline & Region & $49.79^{* *}$ & 8 & 2 & Ankara, Bolu, Şanlıurfa & 2.72 & 211 \\
\hline & & & & 3 & Erzurum & 3.26 & 23 \\
\hline of the wage & Unit & $6.38^{*}$ & 2 & 1 & GDF, GDNCNP & 2.62 & 458 \\
\hline satisfaction. & & & & 2 & GDCDE & 3.40 & 5 \\
\hline & Fxperience & $1680^{* * *}$ & 3 & & $\begin{array}{l}\text { Those who experienced low and medium }\left(\begin{array}{ll}0 & -20 \\
\text { years })\end{array}\right.\end{array}$ & 2.71 & 238 \\
\hline & Experience & & & & $\begin{array}{l}\text { Those who experienced high and very high ( } \geq 21 \\
\text { years) }\end{array}$ & 2.33 & 225 \\
\hline
\end{tabular}

\footnotetext{
* : significant at 0.05 confidence level; **: significant at 0.01 confidence level; DF: degree of freedom; $\overline{\mathrm{X}}$ : arithmetic mean; N: number of individuals in the group
} 
About "the main factors affecting the job satisfaction", both employees (41\%) and experts (36\%) chose the option of "feeling to be beneficial for the society conscientiously" as the first factor. While employees preferred "working independently and applying creativity" as the second factor, the experts preferred "having adequate wages and social security" (Table 4). The ideas of the participants in this respect don't show a significant difference regardless of region, unit, duty and experience (Table 5).

Regarding "level of wage satisfaction", $49 \%$ of the working participants have "medium level" satisfaction, while $11 \%$ have "high" and "very high" satisfaction (Table 4). While the participants' ideas on the matter do not differ depending on the position, a difference at the $99 \%$ confidence level was determined due to the regions and experience, and at the $95 \%$ confidence level according to the units (Table 5). Accordingly, the participants working in the regions of İstanbul, Adana, Antalya and İzmir are generally pleased with the wage taken at "very low" level; the participants working in the regions of Ankara, Bolu and Şanlıurfa have a "medium level" wage satisfaction, while the participants in the region of Erzurum have "high". Likewise, while the participants working in the GDF and GDNCNP generally have "very low" and "medium level" wage satisfaction; while the participants working in the GDCDE are pleased have "medium level" and "high". On the other hand, the participants with low and medium experience ( $\leq 20$ years) have generally "medium level", satisfaction with their wage and those who are high and very high experienced ( $\geq 21$ years) have "very low".

\subsection{Communication, audit and solidarity}

In this section, whether subordinates and superiors could communicate with each other in relation to work, how often and how employees should be supervised, whether they could see the institutional support of higher authorities, and whether employees were in solidarity among themselves, was studied. The responses of the participants to the related questions are presented as percentages in Table 6 , and whether the participants' opinions on this subject are different according to regions, working unit, task and experience were tested with statistical analysis (Table 7). According to this, the following comments and evaluations have been made.

As can be seen in Table 6, 92\% of the participants are "able to discuss the work-related ideas and opinions with subordinates" at the "medium, high and very high level". This indicates that the vast majority of employees are open to debate with the subordinates. The ideas of participants in this respect do not differ according to regions and experience. However, there is a significant difference at 95\% confidence level depending on the units worked, and at 99\% confidence level according to the duty (Table 7). According to the Duncan Test results, which were made to find different groups, while the participants working in the
GDF could generally find the opportunity to discuss their work-related ideas and opinions with the subordinates at the "medium and high level", the participants working in the GDNCNP and GDCDE discuss at the "high level". Similarly, while those who on duty as engineer and operation manager generally discuss the work-related ideas and opinions with subordinates at the "medium and high level"; those who on duty as operation chief, operation manager assistant, branch manager, regional director and assistant generally discuss at the "high level".

About "being able to discuss the work-related ideas and opinions with superiors", $73 \%$ of the employees of the organization stated that they are able to discuss at the "medium, high and very high level" (Table 6). This demonstrates that most of the participants have flexible discussion environment about the work with their superiors as they are with their subordinates. Among the ideas about it, there is no significant difference with respect to the regions, duty and experience. However, there is a significant difference at the $99 \%$ confidence level according to the units worked. Accordingly, while those working in the GDNCNP are generally able to discuss the work-related matters with their superiors at the "medium and high level"; those working in the GDF and GDCDE are generally able to discuss at the "medium level" (Table 7).

Regarding "ideas about the audit system (monitoring and evaluation) in the unit you work", the employees in the Forestry Organization responded the most (32\%), "an objective and an unprejudiced audit should be implemented" (Table 6). The ideas of the employees in this respect do not different according to the regions, units, duty and experience (Table 7).

About "institutional support of the higher authorities", $60 \%$ of employees stated that they receive the support at the level of "very low" and "none" (Table 6). Employees' ideas in this respect issue do not differ according to the regions. However, it is different at the level of $99 \%$ confidence level according to the units worked, and the experience, and at 95\% confidence level according to the duty (Table 7). According to the Duncan Test results, while those working in the GDNCNP generally receive the institutional support of the higher authorities at the level of the "medium level", and the participants working in the GDF and GDCDE usually receive "very low". Similarly, the participants who are holding a position as the operation chief, operation manager assistant, and operation manager generally receive the institutional support of higher authorities' at the "medium level". The participants who are on duty as the engineer, branch manager, region manager and assistant generally receive the stated support at the "very low level". Likewise, while the participants with high or very high experienced ( $\geq 21$ years) usually receive the institutional support at the "very low level"; those with low and medium experienced ( $\leq 20$ years) receive "very low" institutional support. 
Table 6. Ideas of employees about communication, audit and solidarity

\begin{tabular}{|c|c|c|}
\hline Question (Feature) & Option & Percentage of preference $(\%)$ \\
\hline \multirow{5}{*}{$\begin{array}{l}\text { 1. Being able to discuss the } \\
\text { work-related ideas and opinions } \\
\text { with subordinates }\end{array}$} & a) None & 1 \\
\hline & b) Very low & 7 \\
\hline & c) Medium level & 29 \\
\hline & d) High & 48 \\
\hline & e) Very high & 15 \\
\hline \multirow{5}{*}{$\begin{array}{l}\text { 2. Being able to discuss the work- } \\
\text { related ideas and opinions with } \\
\text { superiors }\end{array}$} & a) None & 7 \\
\hline & b) Very low & 20 \\
\hline & c) Medium level & 40 \\
\hline & d) High & 26 \\
\hline & e) Very high & 7 \\
\hline \multirow{5}{*}{$\begin{array}{l}\text { 3. Ideas about the audit system } \\
\text { (monitoring and evaluation) }\end{array}$} & a) Audit frequency should be well adjusted & 16 \\
\hline & b) Audit should be done by the experts & 28 \\
\hline & $\begin{array}{l}\text { c) Audit results should be communicated to relevant units and their } \\
\text { implementation should be followed. }\end{array}$ & 22 \\
\hline & d) An objective and unprejudiced audit should be applied & 32 \\
\hline & e) Other & 2 \\
\hline \multirow{5}{*}{$\begin{array}{l}\text { 4. Institutional support of the } \\
\text { higher authorities }\end{array}$} & a) None & 25 \\
\hline & b) Very low & 35 \\
\hline & c) Medium level & 25 \\
\hline & d) High & 13 \\
\hline & e) Very high & 2 \\
\hline \multirow{5}{*}{$\begin{array}{l}\text { 5. The individual support and } \\
\text { solidarity of colleagues }\end{array}$} & a) None & 8 \\
\hline & b) Very low & 30 \\
\hline & c) Medium level & 37 \\
\hline & d) High & 23 \\
\hline & e) Very high & 2 \\
\hline
\end{tabular}

Table 7. Diversity of ideas of employees on communication, audit and solidarity due to region, unit, position and experience

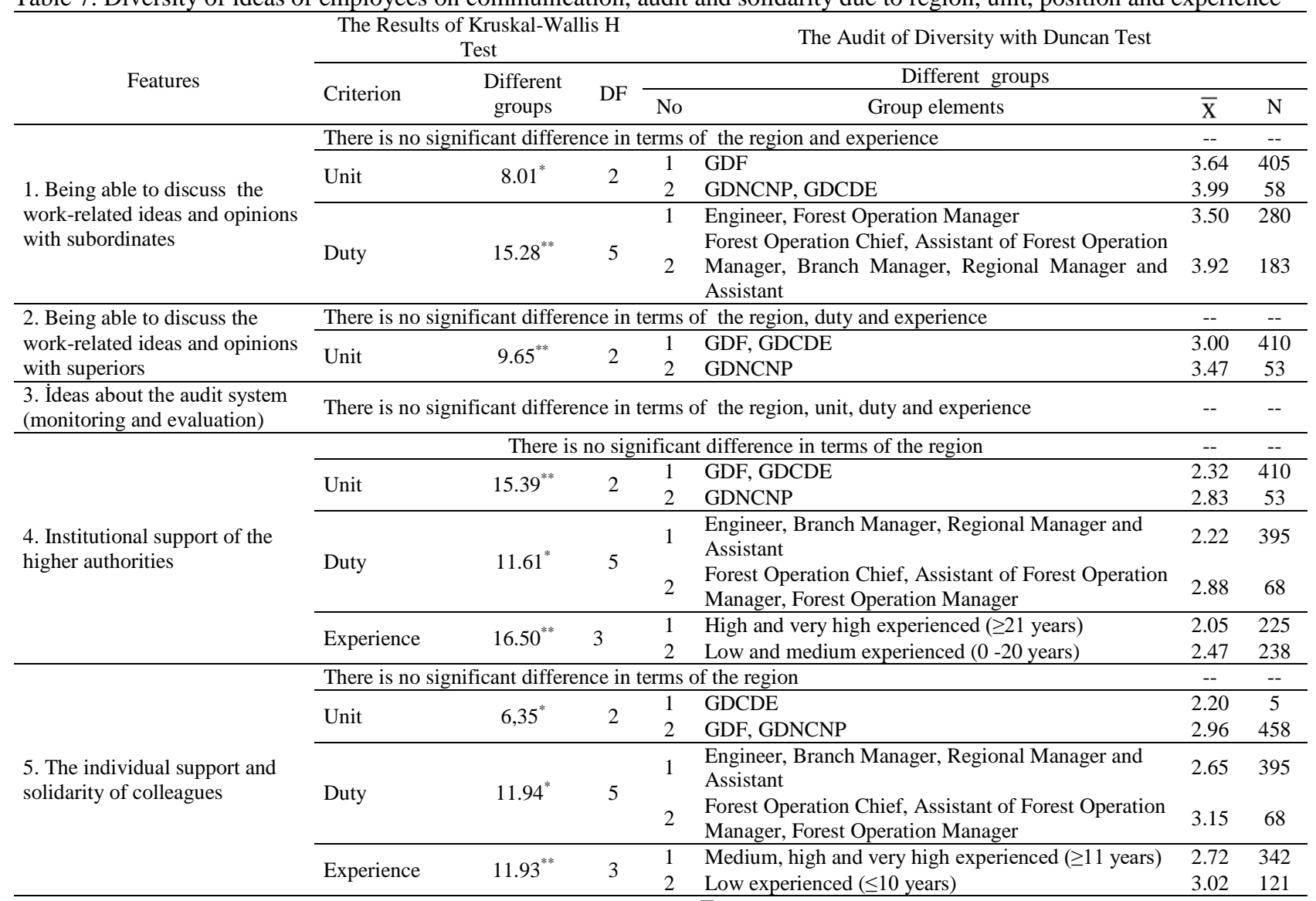

\footnotetext{
* : significant at 0.05 confidence level; **: significant at 0.01 confidence level; DF: degree of freedom; $\overline{\mathbf{X}}$ : arithmetic mean; N: number of individuals in the group
} 
Regarding "the individual support and solidarity of colleagues in any legal status", 75\% of the participants expressed that they receive "no" support and solidarity or "very low" and "medium level" (Table 6). There is no significant difference in terms of the regions worked in the ideas of the participants in this respect. However it was determined that there was a significant difference in the participants' ideas at the $99 \%$ confidence level according to the experience, and at the $95 \%$ confidence level according to the duty done and the units worked (Table 7). According to the Duncan Test results, the employees in the GDF and GDNCNP generally receive the individual support and solidarity of colleagues as "medium level", while the employees in the GDCDE usually receive "very low" support and solidarity. Similarly while those who on duty as operation chief, operation manager assistant and operation manager generally receive the support and solidarity as the "medium level"; those who on duty as engineer, branch manager and regional director and assistant generally receive support and solidarity as "very low" and "medium level". Likewise, while those with low experienced $(\leq 10$ years) receive individual support and solidarity of their colleagues at the "medium level"; those with medium, high and very high experienced ( $\geq 11$ years) generally receive support and solidarity at the "very low and medium level".

\section{Discussion and conclusion}

The job satisfaction of the employees in Turkish forestry are examined and evaluated under three main headings and 13 sub-headings in the form of "the working conditions and workload, organizational expectations and communication, audit and solidarity" in the view of the employees and subject matter experts in this study. For this purpose, two different questionnaire applications consisting of two different interest groups (the employees and subject matter experts) were made on a total of 496 participants in the Turkey's nine geographic regions.

In the study, a large majority of the participants evaluated "unfair and incompetent staff policy" and "political pressures" as "the most significant factors affecting the work efficiency in the Forestry Organization". In the administrative and technical matters in relation to the duty; the employees of the organization mostly state that they cannot transfer their scientific knowledge, ideas and experiences to the implementation process. Also, the employees of the organization and the experts predominately stated that they have been having difficulties in making and applying decisions in accordance with the local conditions. Similar results were obtained in studies conducted by Daşdemir (1998) and Yaman (2010). Toksoy et al. (2006) revealed that the outmost mined areas preventing the job satisfaction are not being in line with the field of expertise of the duty being carried out, unwilled invigilation, in other words, the shifts, and not paying enough amount of importance to the competence in profession. Therefore, these results show the necessity of an arrangement over affair and competent personnel policy, enabling employees to transfer their knowledge and experience into practice easily and thus simultaneously increasing the job satisfaction, and the managerial and organizational success.

In forestry, the priorities, densities and types of the works vary from region to region. For example, while the need for firewood and round wood in the Western Black Sea Region is one of the most significant issues, it is not so significant for the forestry operation directorates in the İstanbul province. Also in İstanbul, jobs such as office works and correspondences, cadaster-ownership works, permission-easement works, fighting against forest crime are at the top of the most significant participants. The managerial activities take a large part of the office hours of the field managers (Yurdakul, 2003). In the Western Black Sea Region, different forestry activities stand out and bear weight. Therefore, while arrangements are made for legislation, it is necessary to consider the circumstances arising from the different local conditions. Likewise, largely authorizing the local administrators might be the most logical way to solve the problems on their spot, in the regulations to be made in the legislation related to the forestry.

A large majority of employees stated that they could not find what they had expected when joining the Forestry Organization, and that they did not believe that occupational expectation would materialize in the near future. In the previous studies done regarding these matters (Daşdemir, 1998; Yaman, 2010), the majority of the participants responded in the same way. Likewise, in a study conducted by Akbaş (2008), similar results, just as not being able to meet the occupational expectations of the forester technical personnel for the future and feeling social and economic anxiety were obtained. Although a long time has passed since the study was carried out, the results of the research indicates that employees could not integrate into the organization they have been working and that they are not satisfied with the work they do. The results of the study revealed that those who are new in the profession had higher professional expectations, which declined over time, and that they got into dissatisfaction. All these results reveal that the personnel policy should be revised in terms of the future of the profession. Because, the job satisfaction of the administrative and technical personnel have critical significance in terms of the organization success and the sustainability of the forestry in the field of forestry where there is a lot of work density and a lot of work type.

The fact that employees have positive attitudes about the work and the workplace ensures the development of job satisfaction. The development of the job satisfaction also ensures the increase of the performance and productivity at the work. It can be said that two significant factors affecting the job satisfaction in this framework are; the individual and organizational factors (Akşit Aşık, 2010). Also Özden and Ekici (2010), in their study, revealed that the majority of forest engineers working in the private sector are not content with their work, and feeling low professional satisfaction, they demand working in the public sector with an increasing rate.

The majority of the participants expressed that they had a great amount of professional satisfaction. In this regard, it was determined that the staff with the least professional satisfaction in the Forestry Organization, are the engineers and operation chiefs in the administrative duties. In the Forestry Organization, the engineers and especially operation chiefs, who are the lowest units in the field of application, are responsible for many works each of which requires significant expertise. It is therefore a very realistic assessment that the engineers and operation chiefs have less 
satisfaction with the work they do when compared to other duties.

The majority of the participants stated "willing to be beneficial for the society" as the most significant factor affecting the job satisfaction. Similarly, Yaman (2010) determined that the most significant factor affecting about $40 \%$ of the job satisfaction in the forestry was as "the feeling to be beneficial to the society conscientiously". Likewise Yllmaz et al. (2009) identified that "conscientious comfort / spiritual well-being" was among the main factors affecting job satisfaction in forestry. In the same way, a study carried out in the İstanbul Regional Directorate of Forestry (Yurdakul Erol and Köse, 2017) puts forward that professional satisfaction is high in terms of fairly distributing the professional opportunities among the personnel, being socially respected in the society and having the opportunity to direct others. Hence, similar results obtained from the researches clearly puts forward that the feeling to be beneficial to the society conscientiously and the social respectability is a significant factor affecting job satisfaction.

The study shows that the majority of the employees in the Forestry Organization have at least "medium level satisfaction with the wages they received". However, those working in big cities have difficulty to satisfy with the wages they receive are. This situation is largely since living cost is higher in big cities. In addition, as the duration of experience increases, it appears that there is dissatisfaction with the wage received. On the other hand, Toksoy et al. (2006), Dursun (2008), Akyüz et al. (2011) and Yurdakul Erol (2016) stated that the most dissatisfied factors are wage, administrational approach and social rights. In addition, Cherecheş et al. (2013) stated that although the level of satisfaction with wages in forestry organization is below $50 \%$, the level of satisfaction with the professional relation with their colleagues is high. It is obvious that the wage satisfaction received has a critical significance in terms of providing satisfaction with the work.

On the other hand, the study reveals that the vast majority of the employees in the organization had an environment allowing to democratically discussing the professional matters with subordinates and superiors. Such a result shows that employees are open to exchange views on the forestry issues, and that intra-organizational communication / intelligibility is well. In this regard, Daşdemir (1998) states that $58 \%$ of forest operation managers are open to discuss the professional issues with their subordinates and superiors, and that they direct the employees to fulfill the operation purposes. Similar results were obtained in a study carried out by Yaman (2010).

Regarding the audit system (monitoring and evaluation) in the Forestry Organization, the employees mostly feel that the audit materialized in relation to the forestry work should be conducted fairly free from any pressure such as political, administrative etc. This is also significant for employees' respect and trust on the organization. In addition, the majority of employees do not feel secure about receiving the institutional support of the senior authorities. The managerial staffs, who are usually in senior administrative positions, feel themselves less secure. Also, as the professional experience increases, the confidences on the senior authorities tend to decrease. Likewise, the majority of participants stated that they did not receive the individual support and solidarity of their colleagues in any legal status. Based on the results of the research, we might conclude that the paradigm increases after promoting to higher posts and the duration of experience increases. It is clear that managers and technical personnel, who hold the management of the forest resources, do not feel safe, and the lack of a fair and controllable audit system is a problematic issue reducing the job satisfaction and success.

Consequently, professional respectability and satisfaction, adequate wage, employee participation in taking the decisions, ensuring top down and down top communication/intelligibility including the employees in the organization, creating an adequate professional discussion atmosphere for the employees with the subordinates and superiors, the implementation of a constructive and guiding audit, far from political and administrative pressures, the legal support of the institution and solidarity among colleagues, the realization of organizational expectations and integration with the organization shall make a positive effect on creating a peaceful work environment and increasing job satisfaction and success. In addition, in terms of the success and efficiency of the organization, it is clear that an organizational structure based on institutionalization and expertise that can adapt to time-dependent changes and management approach is necessary.

\section{Acknowledgement}

This study was produced in the scope of the research project entitled "Development of Alternative Organizational Models for Turkish Forestry" and numbered 10.5301 / 2014-2017 which was supported by the General Directorate of Forestry and carried out by the Marmara Forestry Research Institute Directorate.

\section{References}

Agbozo, G.K., Owusu, I.,S., Hoedoafia, M.A., Atakorah, Y.B., 2017. The Effect of work environment on job satisfaction: Evidence from the Banking Sector in Ghana. Journal of Human Resource Management, 5(1): 12-18.

Akbaş, A., 2008. Problems and expectations of a profession: Example of Forest Engineering. Journal of Chamber of Forest Engineers, Year: 45(10-11-12): 14-21.

Akınc1, Z.B., 1998. Corporate Culture and Organizational Communication. İletişim Yayınları, İstanbul.

Akşit Aşık, N., 2010. A Conceptual evaluation of individual and organizational factors affecting employees and results of job satisfaction. Türk İdare Dergisi, 467: 31-51.

Akyüz, K.C., Koçak, S., Balaban, Y., Yıldırım, İ., Gedik, T., 2011. Investigating job satisfaction level of employees (The case of Muğla Forest District Directorate). SDU Faculty of Forestry Journal, 12(1): 20-26.

Andersson, K., 2013. Local governance of forests and the role of external organization: Some ties matter more than others. World Development, 43: 226-237.

Arnold, E., Silva, N., 2011. Perceptions of organizational communication processes in quality management. Revista de Psicolgia, 29(1): 153-174.

Borca, C., Baesu, V., 2014. A Possible managerial approach for internal organizational communication characterization. Procedia-Social and Behavioral Sciences, 124: 496-503.

Chen, L.H., 2008. Job satisfaction among information system (IS) personnel. Computers in Human Behavior, 24: 105-118.

Cherecheş, C., Toader, R., Toader, C., 2013. Analysis of motivational factors in forestry units. Review of Management and Economic Engineering, 12(2): 107-112. 
Chimanikire, P., Mut, E., Gadzirayi, C. T., Muzondo, N., Mut, B., 2007. Factors affecting job satisfaction among academic professionals in tertiary institutions in Zimbabwe. African Journal of Business Management, 1(6): 166-175.

Coomber, B., Barriball, K.L., 2007. Impact of Job satisfaction components on intend to leave and turnover for hospital-based nurses: A Review of the Research Literature, International Journal of Nursing Studies, 44: 297-314.

Çok, N., Göksu, E., Doğaner, A., Kalkan, B, Güneş, Ö., 2017. The effect of job satisfaction and some individual characteristics of the employees of Elazı $\breve{g}$ Forestry District Directorate on job satisfaction. Turkish Journal of Forest Science, 1(2): 155-168.

Dașdemir, İ. 1996. Determination of Success Levels in the Forest Districts (Example of North-East Anatolia and Blacksea Regions). Ministry of Forestry, Eastern Anatolia Forestry Research Institute, Technical Bulletin No: 1, Erzurum.

Daşdemir, İ., 1998. Determination of Administrative and Organizational Dimensions of State Forest Districts. Ministry of Forestry Eastern Anatolia Forestry Research Directorate, Technical Report Publication Number: 3, Erzurum.

Daşdemir, İ. 2016. Scientific Research Methods. Nobel Academic Publishing and Consulting Trade Limited Company, Ankara.

Dursun, F., 2008. Investigation of job satisfaction levels of employees in state forest enterprises; the case of Kalkım, Yenice, Bayramiç Forest Enterprises. M.Sc. Thesis, Karadeniz Technical University Institute of Science and Technology, Trabzon.

Eğinli, A.T., 2009. Job satisfaction in employees: An investigation on job satisfaction of public and private sector employees. Atatürk University Journal of Economics and Administrative Sciences, 23(3): 35-52.

Erdil, O., Keskin, H., İmamoğlu, S.Z., Erat, S., 2004. The relationship between supervision style, working conditions, coworkers behavior, recognition and job satisfaction: A field research on textile firms. Doğuş University Journal, 5(1): 1726.

Geray, A.U. 1998. National Environmental Action Plan, Forest Resources Management. DPT Publication, Ankara.

Glisson, C., Durick, M., 1988. Predictors of job satisfaction and organizational commitment in human service organizations. Administrative Science Quarterly, 33(1): 61-81.

Gupta, D., Koontz, T.M., 2019. Working together? Synergies in government and NGO roles for community forestry in the Indian Himalayas. World Development, 114: 326-340.

Gümüş, C., 2014. Effects of forestry policies from ottoman to present on forestry organization and current issues. II. National Mediterranean Forest and Environment Symposium, 22-24 October, Isparta, pp.477-489.

Hadikusumo, B.H.W., Jitwasinkul, B., Memon, A.Q., 2017. Role of organizational factors affecting worker safety behavior: A Bayesian Belief Network Approach. Procedia Engineering, 171: 131-139.

Hardy, S.D., Koontz, T.M., 2010. Collaborative watershed partnerships in urban and rural areas: Different pathways to success? Landscape and Urban Planning, 95(3): 79-90.

Hitka, M., Lorincova, S., Gejdos, M., Klaric, K., Weberova, D., 2019. Management approach to motivation of white-colar empl1oyees in forest enterprises. BioResources, 14(3): 54885505.

Hoş, C., Oksay, A., 2015. The relationship between organizational commitment and job satisfaction in nurses. Süleyman Demirel University Journal of Faculty of Economics and Administrative Sciences, 20(2): 1-24.

Iversen, L., Farmer, J.C., Philip, C., Hannaford, P.C., 2002. Workload pressures in rural general practice: a qualitative investigation. Scandinavian Journal of Primary Health Care, 20: $139-144$

Keleş, H.N., 2007. A research done in pharmaceutical production and distribution companies related to the effect of job satisfaction on organizational commitment. Süleyman Demirel University Journal of Social Economic Research, 13: 243-263.
Köse, S., Gönüllüoğlu, S., 2010. A research on determining the effect of organizational support on organizational commitment. Dumlupinar University Journal of Social Sciences, 27: 85-94.

Küçük, F., Bayuk, M.N., 2007. Corporate image of employees as a success factor in crisis environment. Journal of Yaşar University, 2(7): 795-808.

Lund, J.F., Rutt, R.L., Ribot, J., 2018. Trends in research on forestry decentralization policies. Current Opinion in Environmental Sustainability, 32: 17-22.

Matilla-Santander, N., Lidón-Moyano, C., González-Marrón, A., Bunch, K., Martín-Sánchez, J.C., Martínez-Sánchez, J.M., 2019. Attitudes toward working conditions: are European Union workers satisfied with their working hours and work-life balance?. Gaceta sanitaria, 33: 162-168.

Meng, J., Berger, B.K., 2019. The impact of organizational culture and leadership performance on PR professionals' job satisfaction: Testing the joint mediating effects of engagement and trust. Public Relations Review, 45: 64-75.

Nguyen, A.N., Taylor, J., Bradley, S., 2003. Relative Pay and Job Satisfaction: Some New Evidence. Working Paper 045, Department of Economics, Lancaster University Management School.

Opkara, J.O., 2002. The impact of salary differential on managerial job satisfaction: a study of the gender gap and its implications for management education and practice in a developing economy. Journal of Business in Developing Nations, 8: 65-92.

Orhunbilge, A.N. 2000. Sampling Methods and Hypothesis Testing (Review and Expanded Second Edition). Avcrol Printing and Publishing, İstanbul.

Ölçer, N., Koçer, S., 2015. Organizational communication: A survey on the academic staff at Kocaeli University. Global Media Journal, TR Edition, 6(11): 339-383

Örücü, E., Yumuşak, S., Bozkır, Y., 2006. Job satisfaction and its determinants for individuals who works in the banking sector in quality management perspective. Celal Bayar University Faculty of Economic and Administrative Sciences Journal, 13 (1): 39-51

Özcan, E.D., 2011. Organizational structure and job satisfaction from personality perspective. Beta Publishing, İstanbul.

Özden, Ö., Ekici, F., 2010. Past, present and future of forest engineering profession. III. National Black Sea Forestry Congress, 20-22 May, Artvin, pp. 17-23.

Özdönmez, M., Akesen, A., Ekizoğlu, A., 1998. Forest Administration Information. IU Faculty of Forestry Edition No: 4157/401, İstanbul, 301 p.

Özkalp, E., Varoğlu, A., Varoğlu, D., Kırel, A.Ç., Acar, P., 2013. Organizational Behavior. Anadolu University Edition No: 2847, Saray Printing House, Ankara.

Park, J., Kim, Y., Han, B., 2017. Long working hours in Korea: Based on the 2014 Korean working conditions survey. Safety and Health at Work, 8: 343-346.

Porter, L., Lawler, E., 1968. Managerial Attitudes and Performance. The Dorsey Press, Homewood, Illinois.

Rhoades, L., Eisenberger, R., 2002. Perceived organizational support: A review of the literature. Journal of Applied Psychology, 87: 698-714.

Sanchez-Sellero, M.C., Sanchez-Sellero, P., Cruz-Gozalez, M.M., Sanchez-Sellero, F.J., 2018. Determinants of job satisfaction in the Spanish wood and paper industries: A comparative study across Spain. Drvna Industrija, 69(1): 71-80.

Sarode, A.P., Shirsath, M., 2014. The factors affecting Employees work environment and its relationship with Employee productivity. International Journal of Science and Resource, 11(3): 2735-2737.

Soysal, A., Tan, M., 2013. A research in service sector with regard to factors that affect work satisfaction: the case of public and private banking personnel in the Kilis Province. Niğde University Academic Review of Economics and Administrative Sciences, 6(2): 45-63. 
Toksoy, D., Ayaz, H., Bayramoğlu, M.M., 2006. The situation of technical staff of forestry organization and bureaucratic problems faced. Socio-Economic Issues in Forestry Congress Book, 26-28 May, Çankırı. pp. 87-92

Tosun, M., 1981. Organizational Effectiveness. TODAIE Publishing No: 196, Ankara.

Wang, F., 2018. Forest algorithm based staff incentive mechanism design of non-public enterprise from the perspective of positive organizational behavior. Cognitive Systems Research, 52: 132137.

Yaman, F., 2010. Factors affecting organizational and managerial success in forestry. M.Sc. Thesis, Bartın University, Graduate School of Natural and Applied Sciences, Bartın.

Y1lmaz, E., Koçak, Z., 2008. Job Satisfaction Survey for Employees of Eastern Mediterranean Forestry Research Directorate. Eastern Mediterranean Forestry Research Institute, Various Publication No: 8, Tarsus.

Yılmaz, E., Daşdemir, İ., Karabulut, S., Koçak, Z., Polat, O., 2009. Factors Affecting Job Satisfaction of Personnel Working at the Provincial Organization of Forestry General Directorate: The Case Study of Mersin Forestry Regional Directorate and its Forestry Enterprises. Eastern Mediterranean Forestry Research Institute, Technical Bulletin No: 30, Tarsus.
Yurdakul, S., 2003. Problems and results of personnel management in forestry (examining with case study). M.Sc. Thesis, Istanbul University, Institute of Science and Technology, İstanbul.

Yurdakul Erol, S., 2016. Comprehensive analysis of some jobrelated attitudes on expectation and satisfaction among forestry staff: Case results from a Turkish Regional Forestry Organization. International Foretsry Review, 18(2): 161-179.

Yurdakul Erol, S., 2017. Various evaluations on human resources management in forestry in turkey and the state of technical forestry staff. Current Trends in Science and Landscape Management, ISBN 978- 954- 07- 4338- 7, St. Kliment Ohridski University Press, Sofia, 543-561.

Yurdakul Erol, S., Köse, M., 2017. Job satisfaction of forestry technical staff: the case of Regional Forest Directorate of İstanbul. Kastamonu University Journal of Faculty of Economics and Administrative Sciences, 18(1): 273-286.

Zidane, Y.J.T, Hussein, B.A., Gudmundsson, J.O., Ekambaram, A., 2016. Categorization of organizational factors and their impact on project performance. Procedia-Social and Behavioral Sciences, 226: 162-169. 